\title{
The Mediating Effect of Teams Cohesion in the Relationship between Internal Recruitment and Teams Effectiveness at Jordanians Industrial Shareholding Companies
}

\author{
Sahar Moh'd Abu Bakir ${ }^{1}$ \\ ${ }^{1}$ Associate Professor, Business Administration Department, Faculty of Business, Amman Arab University, Jordan \\ Correspondence: Sahar Moh'd Abu Bakir, Associate Professor, Business Administration Department, Faculty of \\ Business, Amman Arab University, Jordan. E-mail: sahar@aau.edu.jo
}

Received: January 27, 2021

Accepted: February 27, 2021

Online Published: March 11, 2021

doi:10.5539/ijbm.v16n4p12

URL: https://doi.org/10.5539/ijbm.v16n4p12

\begin{abstract}
It was proved by research that teamwork in manufacturing organizations increases productivity, enhances organizations efficiency and guarantees quality of outputs. In this context, synergy, cooperation, strong relationships and coordination are essential to achieve the expected yield of teamwork. It is difficult to attain the required level of cohesiveness in the short run and among new employees. So that this study aims to find out the impact that internal recruitment has on both teams effectiveness in terms of (team productivity and quality of performance) and also on teams cohesion as a mediator between internal recruitment and teams effectiveness.

The "Jordanian industrial shareholding companies" formed the population of the study, (43) Companies of these agreed to be part of the study, 260 questionnaires were distributed targeted production managers and supervisors.

The results confirmed the cause and effect relationships between the three variables with the implication that internal recruitment has several benefits not only on teams' effectiveness and teams' cohesion, but also on job satisfaction and job commitment.

Based on the results it is recommended to instill the teamwork spirit and cooperation culture within organizations. Lately this organizational unity became crucial for reducing the negative consequences of the COVID-19 pandemic.
\end{abstract}

Keywords: Jordanians industrial shareholding companies, internal recruitment, teams' effectiveness, teams cohesion.

\section{Introduction}

Organizations are defined as "social entities" formed by group of individuals who gathered to achieve collective objectives, according to Daft (2013) organizations essentially are based on people who are working together in close cooperation and coordination for the organizations benefit.

Bateman, Colin \& Bingham, (2002); Delgado, María \& Gómez (2008); Bucic, Robinson, \& Ramburuth, (2010) illustrated that after the seventieth of the last century organizations became teams oriented, synergy and collective goals dominated the relationships among groups and teams. In accordance to Luthans (2011); Tohidi, (2011) this transfer was attributed to the proposition that if individuals are working together in a collective and interdependency system of work, they will be capable to perform better than if they performed independently.

In the same context Buchanan, \& Huczynski, (2010) mentioned that organizations accomplishment is a function of teams effectiveness, it was confirmed that only effective teamwork enabled organizations to reduce production cost, increase productivity, enhance quality, and create better solutions and innovativeness. Hence teams effectiveness antecedents received the attention of many researchers; Delgado Piña et al., (2008); Markova \& Perry, (2014) argued that teams effectiveness counted on selecting people who own team spirit, who prefer to share duties and responsibilities with others. Moreover Mickan, \& Rodger, (2000); Gächter, Starmer, \& Tufano, (2017) highlighted teams cohesion and members mutual attraction as energizers of teams effectiveness. While HM Tse, (2014) stated that shared experience, trust and mutual respect are likely to attain high levels of teams performance.

Spinelli \& Zajas, (1995); Chan, (1996) remarked that mutual trust among team members and teams cohesion are constructed and promoted over time, they argued that shared experience is difficult to be structured unless 
employees spent long period of time together within the same organization.

Earnest, \& Landis, (2014) suggested Internal recruitment as a strategy through which organizations can create a friendly environment, that makes it easier for employees to be engaged in teams, smooths cooperation and coordination within, and among groups.

Kumar, \& Suresh, (2009) highlighted the yield of internal recruitment and retaining employees; they mentioned that "Long-term employment of loyal workers" and teams work were the main sources of Japanese Industrial firms excellence.

Hence this study aims to examine if "Jordanian industrial shareholding companies" are engaged in internal recruitment than external, and to test the impact of internal recruitment on teams' effectiveness in terms of productivity and quality of work. And finally the study aims to examine the mediating effect of teams' cohesion between the relationship of internal recruitment and teams' effectiveness.

\subsection{The Problem Statement and Its Significance}

According to Jacobs \& Chase, (2010); Kumar, \& Suresh; (2009); Krajewski, Ritzman, \& Malhotra, (2016); Heizer, Render, \& Munson, (2017) the manufacturing organizations' are relied mainly on the productivity of teams; this type of organizations aimed to produce the planned products within the right quantity, quality, time and cost, any negative deviation can be associated with low performance of team work.

The same can be said about the industrial sector in Jordan. In reference to the "Jordan Economic Growth Plan 2018 - 2022" the Industrial sector contributed directly or indirectly in $40 \%$ of the Jordanian GNP, this sector is facing vast of challenges restricted the intended progress, recently Covid- 19 pandemic in addition to escalating competition at the international level diminished this sector's dreams of progress.

The main objective of the Jordanian economic growth plan is to invest in the right pool of human resources to come up with high quality products. Previous research findings shed light on the role of human resources and effective team work as the inimitable source for sustainable competitive advantage particularly in the industrial sector. It was proved either that effectiveness of teamwork can be guaranteed through teams' synergy, cooperation and cohesion.

Dessler (2014); Torrington, Hall, Taylor, \& Atkinson (2014) stated that internal recruitment is a tool for building robustness, synergism in organizations.

So that this study is trying to answer the following questions:

1. Do the "Jordanian industrial shareholdings companies" engage in internal recruitment?

2. Is there an impact of internal recruitment on teams' effectiveness?

3. Is there an impact of internal recruitment on teams' cohesion?

4. Is there an impact of teams' cohesion on teams' effectiveness?

5. Is there an impact of internal recruitment on teams' effectiveness through teams' cohesion as a mediator?

\section{The study Model and Hypotheses}

This study is based on examining the relationship between the following variables:

The independent variable: Internal recruitment in terms of 2 sub variables: employees' transfer, and employees' promotion.

The dependent variable: teams' effectiveness it has also two sub variables: teams' productivity and the quality of team work, and finally (teams' cohesion) as the mediator variable.

The hypothesized relationships between the three variables is presented in figure (1)

\subsection{The Study Model}

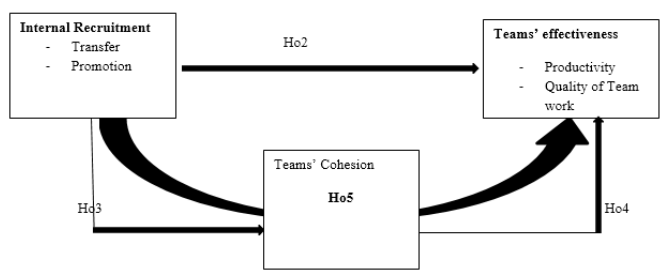

Figure 1. The study's model 


\subsection{The Study's Hypotheses}

Ho1: The Jordanian industrial shareholding companies don't engage in internal recruitment.

Ho2: there is no statistically significant impact of internal recruitment on teams' effectiveness at the Jordanian industrial shareholding companies.

Ho3: there is no statistically significant impact of internal recruitment on teams' cohesion.

Ho4: there is no statistically significant impact of teams' cohesion on teams' effectiveness.

Ho5: There is no statistically significant impact of internal recruitment on teams' effectiveness through teams' cohesion at the "Jordanian industrial shareholding companies".

\section{Theoretical Background and Literature Review}

\subsection{Recruitment}

Recruitment is defined as the "Process of seeking and attracting a pool of people from which qualified candidates for job vacancies can be chosen”. Byars, \& Rue, (2006); Holtbrügge, Friedmann, \& Puck, (2010) explained that human resources are the inimitable resource that addresses organizations challenges, and makes a direct contribution to organizations' sustainability, thus it is pivotal to attract those who are competent to fulfill organizations emptions (Moh'd,2019).

Bernardin (2013) commented that the staffing strategy is responsible for accomplishing organizations' success via human resources. Armstrong \& Taylor, (2014) declared that successful staffing strategy (recruitment, selection and hiring) is ended always with the right pool of human resources.

Recruitment: is the first step, and the most critical. Due to Schroeder, (2012); Snell\& Bohlander, (2013) the effectiveness of recruiting the required candidates is built on human resources planning, in this type of planning the demanded human resources are accurately identified in compatible with organization's future orientation and strategies.

DeCenzo, \& Robbins, (2010) mentioned that after identifying the needed human resources, the next step is determining the sources of recruitment; in their search for the right candidates organizations have two options either internal or external sources. The challenge that creates a confusion to HR management is to find the right balance between the pros and cons of the two sources DeNisi \& Griffin (2010) argued. Choosing one of the two sources on the expense of the other must generate actual advantages for both the employees and the employers (Moser, 2005); (DeVaro \& Morita, 2013).

\subsubsection{Internal Recruitment}

It is known also as "the internal labor market" (ILM), it referred to the process of filling the positions from within the organization, either through transfer or promotion (Aravamudhan \& Krishnaveni, 2016).

\subsubsection{Employees' Transfer}

Transfer can be described as the process of moving an employee from one job to another in the same managerial level, without any change in the rank, or in the employees' formal responsibilities.

Heneman, Judge, \& Kammeyer (2012) commented that usually organizations adopt transfer strategy in order to equip employees with additional skills and knowledge. Das, \& Baruah, (2013) argued that transfer is a tool to acquire the needed competencies for employees' future progress; meanwhile organizations will have the pool of qualified human resources and the means for retaining them.

\subsubsection{Employees' Promotion}

Promotion is the process of transferring the employee to a higher position within the organization, this move is associated usually with an increase in compensations and responsibilities (Mathis \& Jackson 2010).

According to Bakir, (2019) promotion is one of the future planning actions that aims to push employees for more learning and development; it is the yield of employees' good performance and long period of service at the same organization. Within the same context Torrington et al., (2014) underlined promotion role in improving employees' morale that will be translated into higher productivity, commitment and consequently reduces turnover rate.

\subsubsection{Pros and Cons of Internal Recruitment}

Moser (2005); Christensen \& Rog, (2008); DeVaro, Morita, (2013) remarked that internal recruitment enables organizations for more effective and efficient achievements, when employees have full information of the organization, they will be aware of how their organization operates. They have a convenient experience with day- 
to-day tasks, Adeola, \& Adebiyi, (2016) added, current employees are familiar with organizational culture and structure, so that no orientation or training or any kind of socialization are needed. Bakir, (2017) explained that current employees acquired incremental learning over years; accordingly they will be faster and more productive than new employees.

Mathis \& Jackson (2010) illustrated that organizations also guarantee the continuity of operations; an internal employee can easily move into other jobs and perform with minimal downtime.

Maloney,(2018) argued that internal recruitment equips employees with job security, increases their satisfaction, and they will be sure that they have the opportunity for advancement and promotion.

Meanwhile DeVaro \& Morita, (2013) stated in spite of the advantages of internal recruitment; this method may have the drawback of raising conflict among employees. DeVaro \& Morita, (2013) added that promoting one employee over another can create disagreement in the work place, in a level will diminish performance effectiveness.

Another drawback introduced by Heneman, et al., (2012) they argued that the symmetry and routine methods in operations; will maintain status quo without allowing new ideas or methods to emerge into the organization.

\subsubsection{External recruitment}

External recruitment is perceived as the most familiar strategy for recruiting talents with diverse ideas and creative solutions (Muscalu, 2015). This strategy has the advantage of bringing to the organization new knowledge, different experiences, despite that it will sometimes affect employees' motivation badly Gërxhani, \& Koster, (2015) argued.

Das, \& Baruah, (2013) illustrated that external recruitment might equip organizations with creative individuals. But these new comers will lack sufficient information related the organization, their colleagues, and the nature of the tasks that had to be completed, additionally building mutual trust with current employees will take time.

\subsection{Teamwork}

\subsubsection{Team Definition and Forming}

The team is defined as a group of people (minimum two), brought together to achieve common goals (Kozlowski, \& Ilgen, 2006); they are embedded in one system (Locke, 2009); thus their attitudes, behavior and mindset must be changed from being an association of strangers to a unified body.

Mustafa, Glavee \& Rice, (2017) described the positive attitude of being a group member as (team oriented employee), referring to those who prefer to be part of a group than performing individually. Tuckman \& Jensen, (2010) argued that team members will not reach this level of (team orientation) until they have gone through Tuckman’s (1965) 4 stages of group building "forming," "storming," "norming," and "performing" .

Forming is the first stage where ambiguity and unanswered questions are the denominated features, in the second stage (storming) fluctuations of perceptions, competition, and conflict between members surfaced, based on leaders interventions accompanied with the members determination they handle these challenges and move into the third stage (Norming) in which an agreement among members on the rules and clear collective road map are build up.

Performing - is the last stage where the members are transfered into team work oriented people, and they became eager for accomplishment.

\subsubsection{Teams Effectiveness}

Teams effectiveness has attracted the attention of researchers; not only to find a definition and indicators, but also to identify the antecedents that build teams effectiveness in organizations (Delgado., et al., 2008); Kozlowski, \& Ilgen, (2006) argued that the concept is based on the logic of "inputs-processes-outputs" where inputs linked to team composition and resources, processes are the conversion activities, while the third element outputs is linked to three basic facets: team performance, team members satisfaction and finally their willingness to stay within the team.

Bucic et al., (2010); HM Tse, H. (2014) underlined the harmony among team members, the way they coordinate and exchange resources and share knowledge as indicators of team effectiveness.

While Luthans (2011) perceived teams effectiveness as the degree of interdependency between tasks and the harmony among team members to achieve these tasks in compatible with the strategic plans.

Peñalver, Salanova, Martínez, \& Schaufeli, (2019) highlighted team cohesion to articulate the effectiveness of 
team members' performance.

However Daft (2010); characterized teams effectiveness as the capacity of the team members to produce the convenient quantity and quality in addition to their ability to learn and to adapt to changes.

Tohidi, (2011) argued that team effectiveness can be measured by team productivity and the degree of products' fitness to quality standards. According to Krajewski et al., (2016) teams' effectiveness can be evaluated through the degree to which team members are skilled enough to complete their tasks efficiently.

For this study teams effectiveness is exhibited in the next sections using team productivity, and team work quality as indicators of the concept.

\subsubsection{Team Productivity}

According to Heizer, et al., (2017) productivity is a central performance measure in manufacturing organizations, in spite that productivity sometimes is used interchangeably with production, but actually they are not the same; Krajewski et al., (2016) commented.

Production referred to the volume of outputs, while productivity is the rate between inputs to outputs.

Kumar \& Suresh, (2009) defined productivity as the best combination of resources (inputs) to transform them into products with higher value than the basic inputs.

Jacobs \& Chase, (2010) illustrated that the key to productivity is the rational utilization of scarce resources while sustaining high outputs, hence productivity determines the organizations' efficiency and profitability, the higher the productivity is, the greater will be team performance.

Due to Russell \& Taylor, (2011) productivity must be joined with quality; organizations which are able to produce in high quality can increase productivity, they will have the opportunity to control cost, and reduce products price, raise their sales volume, support their market positioning and market share, and achieve profitability.

\subsubsection{Quality of Team Work}

Quality is a measure of excellence; Heizer, et al., (2017) added in manufacturing organizations quality is the consistency with specified standards, and free from defective outputs.

Stevenson, \& Sum (2010) illustrated that quality from organizations' perception is related to the conformity with the planned specifications, planned cost, speed, and free of mistakes units. Reid, \& Sanders, (2012) cleared out that manufacturing organizations aimed high quality products, but without ignoring the optimal utilization of resources and total cost.

Russe \& Taylor, (2011) argued efficiency and effectiveness are two complementary objectives, organizations had to find the right balance between high standards products with the minimum cost.

Buchanan, \& Huczynski, (2010) demonstrated that these objectives can be obtained through collective efforts of production teams.

McClurg, Chen, Petruzzelli, \& Thayer, (2017) findings affirmed the functionality of synergy among team members to accomplish the targeted performance; any inconsistency will have negative consequences. McClurg et al., (2017) findings underlined the positive association between teams' cohesion and the quality of performance.

\subsubsection{Teams Cohesion}

During the fifties of the last century the term cohesion had its significance in business research. In reference to the Latin language it means "to stick together".

Due to the significance of the term in organizations' success, many studies were conducted since then to find out the factors that motivate persons to stick together for achieving collective goals. Others were interested in examining the association between teams cohesion and organizations performance as Mach, M., Dolan, S., \& Tzafrir, S. (2010); Mach, et al., (2010) remarked.

Festinger, (1950) described cohesion as the interpersonal attraction between members, it is the feeling of pride to be part of the group and the commitment to group accomplishments.

Gross \& Martin (1952) commented that team cohesiveness has 2 dimensions: the interpersonal cohesion; which can be explained by group members' unity, and the degree of attraction to each other that energizes them for value added cooperation. The second dimension is "task cohesion" Gross \& Martin (1952) viewed the first dimension as a prerequisite for the second; in other words without team members cooperation the planned tasks will not be performed properly. 
Bennis, \& Shepard, (1956) went further than attraction, they argued that group maturity will build cohesion, the mature group resolves its conflicts easily, overcomes obstacles, facilitates communication, creates consensus and finally all the members in mature groups are team oriented.

In (1965) Lott, \& Lott, once again highlighted the role of attraction among the members of the group as an indication of team cohesion.

Zaccaro, \& Lowe. (1988) emphasized the notion that cohesion is a multi- dimensional aspect; they underlined what was introduced in previous literature concerning the interpersonal and task cohesion, their results evidenced that cohesion in its two dimensions affected team performance positively.

Mullen, \& Copper, (1994); Kozlowski, \& Ilgen, (2006); HM Tse, H. (2014); Kebaili, Zanina, \& Arfa, (2015) emphasized the positive impact of cohesion on team performance, their findings revealed that team members interaction, and coordination are antecedents of team success.

In the same context Gächter, et al., (2017) remarked that the more time people work together within the same organization, the easier it will be to build cohesive teams and synergy.

\section{Research Methodology}

\subsection{The Study Population, Sample and Sampling Unit}

The "Jordanian public shareholding Industrial organizations" represented the population of the study; the rationale of choosing this sector because the industrial organizations relied mainly on collective efforts and teamwork. Krajewski et al., (2016) confirmed that in this type of organizations it is rare to perform individually.

This study encompasses all Jordanian Industrial organizations listed at Amman Stock Exchange as public shareholding organizations totaling (59) due to the "Jordanian Depository Center" statistics / 2020.

(43) Companies of these agreed to be involved in the study.

For collecting the needed data and information, the questionnaire was used, 260 questionnaires were distributed by e-mail to production managers and production supervisors, 251 questionnaires retrieved, out of which 6 questionnaires weren't completed properly, and therefore 245 questionnaires were statically analyzed.

The reason for relying on the questionnaire is connected to the facts that the questionnaire requires less time and efforts, it gives researchers the opportunity to collect data from large sample, and it is less expensive than the interview (Zikmund, Babin, Carr, \& Griffin, 2013).

\subsubsection{Respondents' Characteristics}

The sampling and analysis unit covered production managers and supervisors.

The results of frequency and percentage of their characteristics in terms of (gender, age, education, and years of experience) show that $29.4 \%$ of the respondents are females and $70.6 \%$ are males,

$52.3 \%$ of them were between $35-45$ years old, $28.5 \%$ were between $25-35$ years old, and $19.2 \%$ were more than 45 years old.

$17.8 \%$ of the respondents have less than Bachelor degree of education, $48.7 \%$ have Bachelor degrees, $25.1 \%$ have Master degrees, and $8.4 \%$ have $\mathrm{Ph} . \mathrm{D}$ degrees. When it comes to years of experience; $10.6 \%$ of the respondents have less than 5 years of work experience, $48.7 \%$ have between $5-10$ years of work experience, and $40.7 \%$ have more than 10 years of work experience.

\subsection{The Questionnaires' Structure, Validity and Reliability}

The researcher developed a 4 sections questionnaire, which was organized as follows:

The first section contained respondents' characteristics in terms of (gender, age, education, and years of experience).

The other three sections were constructed to measure the study's 3 main variables based on Likert 5 scale measurement "Strongly agree ( 5 points), agree ( 4 points), neutral ( 3 points), disagree ( 2 points), and strongly disagree (1 point)".

Relied on Chan, (1996); Adeola \& Adebiyi, (2016) the second section contained 10 questions utilized to measure internal recruitment (transfer and promotion).

The respondents were asked to express the degree to which their organizations depend on the existed employees to fill the vacancies either through transfer within the same managerial level from one department to another, or through promotion from a lower level to a higher managerial level. And they were asked if the organizations 
provide them with the needed knowledge and skills for occupying the new jobs.

The third section of the questionnaire was made up of 12 questions to measure teams' effectiveness. Based on Delgado Piña et al., (2008); Bateman, et al., (2002); Krajewski et al., (2016). 5 questions out of the 12 were related to teams productivity; in terms of producing the right quantity within the planned time, and if employees have the sense of accomplishment. While the other 7 questions were developed to measure the quality of performance in terms performance accuracy, reduction of (defects, mistakes, and waste) in addition to the rationality of resources utilization.

The last part comprised 8 questions which were employed to measure the mediator variable (teams' cohesion) based on what was introduced by Mach et al., (2010) and Gächter et al., (2017).

The respondents were asked about their relationship with their colleagues, and the degree of cooperation in solving problems and making decisions, they were asked either if they are sharing work responsibility and understand each other roles, and finally they were asked about their readiness to help each other, and their commitment to teamwork.

The validity of the questionnaire was checked by specialized instructors in Human Resources Management and Organizational Behavior.

For examining the reliability of the questionnaire Cronbach Alpha Coefficient for internal consistency was estimated. According to Sekaran, \& Bougie, (2016) if the results of this measurement $=$ or exceed $70 \%$ it is an indication that the questionnaire is reliable.

Table (1) manifests the values of Cronbach's Alpha, the table shows that the values are between $(0.73)$ and $(0.88)$ which means that the questionnaire is reliable.

Table 1. The results of Cronbach Alpha

\begin{tabular}{|c|c|c|c|c|c|c|c|}
\hline Variable/s & $\begin{array}{l}\text { Cronbach } \\
\text { values }\end{array}$ & Alpha & $\begin{array}{ll}\text { No. } & \text { of } \\
\text { questions } & \\
\end{array}$ & $\begin{array}{l}\text { Variable/s } \\
\text { (employees 'needs) }\end{array}$ & $\begin{array}{l}\text { Cronbach } \\
\text { value }\end{array}$ & Alpha & $\begin{array}{ll}\text { No. } & \text { of } \\
\text { questions } & \end{array}$ \\
\hline $\begin{array}{l}\text { Internal } \\
\text { recruitment }\end{array}$ & 0.88 & & 10 & $\begin{array}{l}\text { Teams } \\
\text { effectiveness }\end{array}$ & 0.79 & & 12 \\
\hline Promotion & 0.84 & & 5 & Productivity & 0.81 & & 5 \\
\hline \multirow[t]{2}{*}{ Transfer } & 0.82 & & 5 & $\begin{array}{l}\text { Quality of team } \\
\text { work }\end{array}$ & 0.73 & & 7 \\
\hline & & & & $\begin{array}{l}\text { Teams cohesion } \\
\text { ( Total) }\end{array}$ & 0.86 & & 8 \\
\hline
\end{tabular}

\section{Statistical Analysis Results}

In the following sections the researcher tried to answer the study questions and test its' 5 hypotheses.

\subsection{Descriptive Statistics Results}

In this section the arithmetic means and standard deviations of respondents' answers were computed, the purpose is to explore their agreement related the questions' content in comparison with the neutral mean (3).

Table (2) displays the total means and standard deviations of the three variables (the Independent, the dependent and the mediator). The results were as follows:

The arithmetic mean of (Internal recruitment $)=3.64$, for transfer $=3.86$ and for promotion $=3.41$, It is obvious that all the means are above the threshold (3) which indicated that the respondents realized that the surveyed organizations invested in internal recruitment as the priority to meet human resources demand.

The table shows also that the total mean of teams effectiveness $=(3.43)$, team productivity $=(3.30)$ and (team work) quality $=(3.55)$. The arithmetic means of team's effectiveness revealed that there is a level of satisfaction among respondents related team's' performance, particularly quality. 
Table 2. descriptive results

\begin{tabular}{llll}
\hline Study variables & Mean & Std. Deviation & Std. Error Mean \\
\hline Internal recruitment & 3.64 & .79111 & .05054 \\
Transfer & 3.86 & .64263 & .04106 \\
Promotion & 3.41 & .72349 & .04622 \\
Teams effectiveness & 3.43 & .40237 & .02571 \\
Team productivity & 3.30 & .92346 & .05900 \\
Team work quality & 3.55 & .67658 & .04322 \\
Teams cohesion & 3.49 & .84334 & .05388 \\
\hline
\end{tabular}

Note. $\mathrm{N}=245$.

The last row in table 2 shows that the total mean of teams cohesion $=3.49$ with 0.84 standard deviation.

The respondents answered 8 questions related to the degree of cooperation, synergy, and attraction among team members, and the team members' readiness for collective work, and the degree to which they act in systems thinking mindset.

\subsection{Testing Hypotheses Results}

To test Ho1, one sample t test was used, with test value $=3$ and the confidence interval $=95 \%$

The acceptance decision of Hol is based on t sig value. According to Sekaran, \& Bougie, (2016) the null hypothesis will be rejected if $\mathrm{t}$ sig level is less than 0.05 .

For testing Ho2 and Ho3 multiple regression was used, and simple regression was utilized for testing Ho4.

The decision rules for Ho2, Ho3 and Ho4 will be as follows:

The model will be convenient for regression test if the value of $\mathrm{F}$ sig is less than 0.05 .

The null hypotheses (Ho2, Ho3, and Ho4) will be rejected if t sig level is less than 0.05 .

\subsubsection{Hol results}

Table 3 displays one sample $t$ test, encompassing the values of $t$, and $t$ sig for the independent variable and its 2 dimensions as follows: Internal recruitment: $\mathrm{t}=10.579$ at 0.000 , Transfer: $\mathrm{t}=20.927$ at 0.000 and Promotion: $\mathrm{t}=$ 8.941 at 0.000 .

It is apparent that the sig level of the three variables are less than 0.05 , based on the previously mentioned rule, Hol will be rejected to confirm that the surveyed organizations are engaged in internal recruitment.

Table 3. Ho1 results

\begin{tabular}{llllll}
\hline The Independent Variable & \multicolumn{2}{c}{ Test Value = 3 } & & & \\
& $\mathbf{t}$ & Sig. (2-tailed) & \multicolumn{2}{c}{$\begin{array}{l}\text { Mean } \\
\text { Difference }\end{array}$} & $\begin{array}{l}\text { 95\% Confidence Interval of the } \\
\text { Difference }\end{array}$ \\
\hline Internal Recruitment & 10.579 & .000 & .53469 & .4351 & .6342 \\
Transfer & 20.927 & .000 & .85918 & .7783 & .9401 \\
Promotion & 8.941 & .000 & .41327 & .3222 & .5043 \\
\hline
\end{tabular}

\subsubsection{Ho2 Results}

Table (4) displays the results of the multiple regression which are distributed into the model summery, ANOVA \& coefficients,

The first value in table (4) is $\mathrm{R}=0.584$ which represents a positive moderate correlation between internal recruitment and teams effectiveness.

The value of $\mathrm{R}^{2}(0.341)$ means that $34.1 \%$ of the variation in teams effectiveness is caused by internal recruitment. The table manifests also the value of $\mathrm{F}$ which $=(62.549)$ at $0.000 \mathrm{sig}$ level.

Based on the above mentioned rule the model is suitable for testing the impact of internal recruitment on teams effectiveness.

The coefficients section in the table shows the values of $t$ and $t$ sig which are for transfer $t=(3.704)$, at $(0.000)$ sig

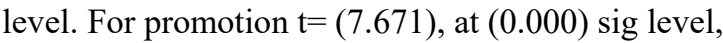

The results of $\mathrm{t}$ sig are less than 0.05 indicated a statistically significant impact of internal recruitment dimensions 
on teams' effectiveness. Promotion has the highest impact due to the value of Beta (0.451).

Additionally, the table displays the values of $\mathrm{B}(0.136)$ which signalized that any increase in one unit in employees transfer will increase teams effectiveness by $13.6 \%$, and the value of B $(0.251)$ means that any increase in one unit in promotion will have an increase $=25.1 \%$ in teams effectiveness.

Table 4. Ho2 results

\begin{tabular}{lllll}
\hline $\begin{array}{l}\text { Model summary results \& ANOVA Results } \\
\text { R }\end{array}$ & R Square & Adjusted R Square & F & Sig. \\
\hline $.584^{\mathrm{a}}$ & .341 & .335 & 62.549 & $.000^{\mathrm{b}}$ \\
Coefficients & & & & \\
Independent variables & $\mathbf{B}$ & $\mathbf{B e t a}$ & $\mathbf{t}$ & $\mathbf{T}$ sig \\
(Internal recruitment) & & & 16.589 & .000 \\
(Constant) & 2.256 & .218 & 3.704 & .000 \\
Transfer & .136 & .451 & 7.671 & .000 \\
Promotion & .251 & & & \\
\hline
\end{tabular}

\subsubsection{Ho3 Results}

Table 5 presents the multiple regression results that measure the impact of internal recruitment on team cohesion. In the table the correlation between internal recruitment and teams cohesion $\mathrm{R}=0.661$ which indicated a positive strong relationship between the 2 variables, $\mathrm{R}^{2}$ value (0.436) reveals that $43.6 \%$ of the variation in team cohesion is a consequence of internal recruitment. F value (93.686) at 0.000 sig level indicated an acceptable model for regression test.

The table shows that $t$ sig values for transfer and promotion $=(0.000)$, evidenced a statistically significant impact of internal recruitment dimensions on teams cohesion.

Based on Beta weight (0.444) it is obvious that transfer has the stronger impact on teams' cohesion than promotion. The table also displays the values of B (0.583) and (0.380) respectively which imply that any increase in one unit of employees transfer will increase teams' cohesion by $58.3 \%$, and any increase in one unit of employees' promotion will increase teams' cohesion by $38 \%$.

Table 5. Ho3 results

\begin{tabular}{|c|c|c|c|c|c|}
\hline \multicolumn{6}{|c|}{ Model summary results \& ANOVA Results } \\
\hline $\mathbf{R}$ & R Square & \multicolumn{2}{|r|}{ Adjusted R Square } & $\mathbf{F}$ & Sig. \\
\hline $.661^{\mathrm{a}}$ & .436 & & .432 & 93.686 & 0.000 \\
\hline \multicolumn{6}{|l|}{ Coefficients } \\
\hline $\begin{array}{l}\text { Independent variables ( Internal } \\
\text { recruitment) }\end{array}$ & B & Beta & $\mathbf{t}$ & T sig & \\
\hline (Constant) & .206 & & .782 & .435 & \\
\hline Transfer & .583 & .444 & 8.174 & .000 & \\
\hline Promotion & .380 & .326 & 5.996 & .000 & \\
\hline
\end{tabular}

\subsubsection{Ho4 Results}

To test Ho4 simple regression is estimated to examine the impact of teams' cohesion on teams' effectiveness.

The results in table 6 show that $\mathrm{R}=(0.645)$ implies a positive strong association between teams cohesion and teams effectiveness. The value of $\mathrm{R}^{2}(0.415)$ indicated that $41.5 \%$ of the variation in teams effectiveness is due to teams cohesion, F sig $(0.000)$ evidenced a suitable model for testing regression and $\mathrm{T} \operatorname{sig}(0.000)$ revealed that there is a statistically significant impact of teams cohesion on teams effectiveness.

Table 6 also manifests that B value $=(0.308)$ denoting a unit increase in teams' cohesion will increase teams' effectiveness by $30.8 \%$. 
Table 6. Ho4 results

\begin{tabular}{lllll}
\hline $\begin{array}{l}\text { Model summary results \& ANOVA Results } \\
\text { R }\end{array}$ & R Square & Adjusted R Square & F & Sig. \\
\hline $.645^{\mathrm{a}}$ & .415 & .413 & 172.698 & $.000^{\mathrm{b}}$ \\
$\begin{array}{l}\text { Coefficients } \\
\text { Independent variables }\end{array}$ & $\mathbf{B}$ & & \\
(Internal recruitment) & & Teta & T sig \\
(Constant) & 2.610 & & 32.392 & .000 \\
& .308 & .645 & 13.141 & .000 \\
\hline
\end{tabular}

\subsubsection{Ho5 Results}

To test Ho5 Path Analysis was estimated using Amos software, supported by the SPSS program, with 0.05 sig level for hypothesis acceptance. This type of analysis is used to examine the strengths of direct and indirect relationships among group of variables, and when there are multi independent or dependent variables (Garson, 2016).

The results that are manifested in Figure (2) and table (7) indicated a statistically significant impact of internal recruitment on teams effectiveness with cohesion as a mediator variable based on the values of $\left(\mathrm{Chi}^{2}=45.52\right)$, and CMIN $=(1.231)$, with significance $(\mathrm{P}=0.000)$, which is less than $(0.05)$.

The results in table 7 show that the "goodness of fit index" (GFI) $=0.9741$, according to (Garson, 2016) if (GFI) exceeds 0.9 it is treated as a good model.

The table manifests the "Comparative Fit Index" $(\mathrm{CFI})=0.9351$ this result is considered convenient, the closer this measure to (1) the better will be. The table also manifests the value of "Root Mean Square Error of Approximation" (RMSEA) which indicated lack of fit compared to the saturated model, the closer (RMSEA) to 0 the better. $($ RMSEA) $=0.0651$ signalized an adequate fit of the model, and the problem of lack of fitness is not existed.

Table 7 displays also the followings:

The standardized direct effect of internal recruitment on teams cohesion $=(0.7340)$ at 0.000 sig level.

The standardized direct effect of teams cohesion on teams effectiveness $=(0.4258)$ at 0.000 sig level

The standardized direct effect of internal recruitment on teams effectiveness $=(0.2980)$ at 0.000 sig level.

While the indirect standardized effect of recruitment on teams effectiveness with teams cohesion mediation $=$ (0.3125) at sig level (0.000)

The results of sig levels of all the mentioned effects mean that there is a statistically significant impact of internal recruitment on teams' effectiveness through teams' cohesion as a mediator and also the results of Ho2, Ho3and Ho4 are confirmed.

Table 7. The results of Ho5

\begin{tabular}{|c|c|c|c|c|c|c|c|c|c|}
\hline CMIN & CMIN/DF & GFI & CFI & RMSEA & $\mathrm{P}$ & Variables & Direct effect & Indirect effect & Total effect \\
\hline \multirow[t]{4}{*}{45.52} & 1.231 & 0.9741 & 0.9351 & 0.0651 & 0.00 & $\begin{array}{l}\text { Internal Recruitment } \rightarrow \\
\text { Cohesion }\end{array}$ & .73400 & --- & .73400 \\
\hline & & & & & & $\begin{array}{l}\text { Cohesion } \rightarrow \\
\text { Teams effectiveness }\end{array}$ & .42580 & --- & .42580 \\
\hline & & & & & & $\begin{array}{l}\text { Internal Recruitment } \rightarrow \\
\text { Teams effectiveness } \\
\text { Internal Recruitment } \rightarrow\end{array}$ & .29800 & & \\
\hline & & & & & & $\begin{array}{l}\text { Teams cohesion } \rightarrow \\
\text { Teams effectiveness }\end{array}$ & & 0.3125 & 0.6105 \\
\hline
\end{tabular}

The indirect effect

$.7340 \mathrm{X} .4258=0.3125$

$0.3125+.2980=0.6105$ 


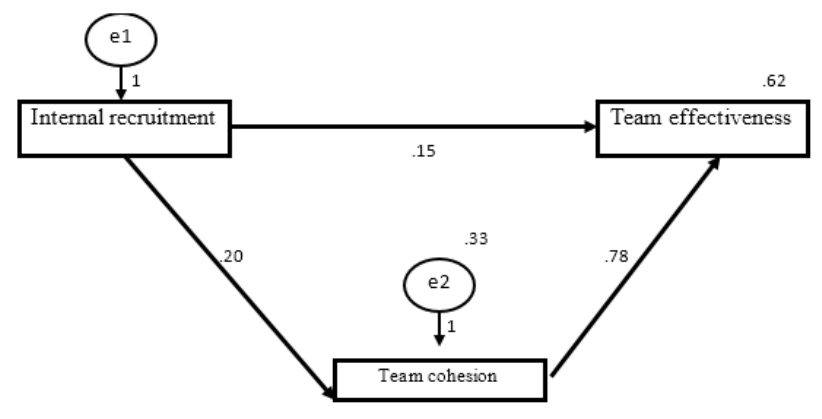

Figure 2. The mediation model

\section{Discussion, Implications and Recommendations}

Andrew Carnegie the American industrialist who led the tremendous expansion of the American steel industry in the late 19th century, elucidated team work as "The ability of individuals to work together towards a common vision"

He commented also that team work "is the fuel that allows common people to attain uncommon results".

His definition confirmed what was proved later by research; that team work in manufacturing organizations increases productivity, enhances organizations efficiency and guarantees quality of outputs.

In this context, synergy, cooperation, strong relationships and coordination are essential to achieve the expected yield of team work.

It was also proved that robust relationships, mutual understanding and shared values need time to be built. So that it is difficult to attain the required level of cohesiveness when team members are new employees; according to Chan, (1996); Moser (2005); Holtbrügge et al., (2010); Dessler (2014); Torrington et al., (2014) the degree of cooperation is greater in organizations that adopt internal recruitment strategy.

In this study the researcher tried to find out if "The Jordanian industrial shareholding companies "are engaged in internal recruitment and the impact of internal recruitment on teams' effectiveness, and on teams' cohesion. And finally the study aimed to examine the mediating effect of teams' cohesion in the impact of internal recruitment on teams' effectiveness.

The results of Hol revealed that the surveyed companies believed in internal recruitment as the first strategy to meet human resources demand, additionally, the results of Ho2, Ho3 indicated that internal recruitment in terms of (transfer and promotion) has a statistically impact on teams effectiveness, and on teams cohesion ( respectively).

The results of Ho4 revealed that teams' cohesion has a statistically significant impact on teams' effectiveness. However the results of Ho5 confirmed the mediating effect of teams' cohesion between the impact of internal recruitment and teams effectiveness.

The above mentioned results underlined the vital role of teamwork and teams cohesion in manufacturing organizations.

These findings are consistent with the propositions and suggestions that were introduced by Bucic et al., (2010); HM Tse, H. (2014); McClurg et al., (2017); Gächter, et al., (2017); and Peñalver, et al., (2019).

The study has several implications related to the manufacturing organizations, can be listed as follow:

The first practical contribution of the study is that it highlighted the importance of internal recruitment for building good relationships inside organizations and in supporting harmony and cooperation among team members.

The second implication is focused on teams' effectiveness which is embodied in the capacity team members have, and their intention to accomplish collective goals.

The study also underlined team spirit and team members' awareness of the complementary and interdependently of their tasks at the level of the team and with other teams in the organization, and the contribution this awareness has on organizations performance.

One of the concepts the study shed light on is synergy that had to be embedded in the organizations' systems and strategy.

Additionally, the study manifests the magnitude of team structure to attain teams cohesion and in return better 
performance, accordingly management must be cautious in building teams in which cooperation must prevails over conflict.

In spite of the above mentioned crucial topics, still there are several pitfalls of internal recruitment, particularly the limitation of attracting new bloods with diverse experience and solutions. To avoid these non-preferable shortages of internal recruitment, it is recommended equipping employees with development programs that enable them to be up to date with external environment changes.

In order to achieve organizational superiority employees need to be informed with what competitors have, the successful stories in the manufacturing sector and other sectors would be beneficial, benchmarking with best practices will represent a base for developing improvement plans.

Finally for future research, the limitation of this study can be rectified by taking into consideration the perception of the lower managerial levels at the manufacturing organizations, and to extend the survey questions to encompass external recruitment too.

Further work can be conducted at services organizations to highlight the significance of team work on the performance of such organizations.

\section{References}

Adeola, M. M., \& Adebiyi, S. O. (2016). Employee motivation, recruitment practices and banks performance in Nigeria. International Journal of Entrepreneurial Knowledge, 4(2), 70-94. https://doi: 10.1515/ijek-20160015

Aravamudhan, N. R., \& Krishnaveni, R. (2016). Capacity building as a new template for diagnosing, assessing and improving recruitment and selection activity: An Indian case study. Journal of Contemporary Management Research, 10(2). 34-57.

Armstrong, M., \& Taylor, S. (2014). Armstrong's handbook of human resource management practice. London, Kogan Page Publishers.

Bakir, S. M. A. (2009). Career Path Management between the Theory and Application: Measuring its Relationship with Satisfying Employees' Needs: A study on the Jordanian Commercial Banks (2019). International Journal of Business and Management, 14(8), 10-24. https://doi.org/10.5539/ijbm.v14n8p10

Bakir, S. M. A. (2017). The Reality of Applying Human Resources Diversity Management and It's Impact on Workers' (Performance, Cooperation, Commitment and Loyalty): A Field Study on the Jordanian Food Industry Companies. International Business Research, 10(3), 183-192. https://doi.org/10.5539/ibr.v10n3p183.

Bateman, B., Colin Wilson, F., \& Bingham, D. (2002). Team effectiveness-development of an audit questionnaire. Journal of Management Development, 21(3), 215-226. https://doi.org/10.1108/02621710210420282

Bennis, W. G., \& Shepard, H. A. (1956). A theory of group development. Human Relations, 9(4), 415-437. https://doi.org/10.1177/001872675600900403

Bernardin, H. J. (2013). Human Resource Management: An Experiential Approach (6th ed.). New York, NY: McGraw-Hill/Irwin.

Buchanan, D. A., \& Huczynski, A. A. (2010). Organizational Behavior (7th ed.). Rotolito Lombarda, Financial Times Prentice Hall.

Bucic, T., Robinson, L., \& Ramburuth, P. (2010). Effects of leadership style on team learning. Journal of Workplace learning, 22(4), 228-248. https://doi.org/10.1108/13665621011040680

Byars, L., \& Rue, W. (2006). Human resource management ( $8^{\text {th }}$ ed.). Boston: McGraw Hill Irwin.

Chan, W. (1996). External recruitment versus internal promotion. Journal of Labor Economics, 14(4), 555-570. https://doi.org/10.1086/209822

Christensen Hughes, J., \& Rog, E. (2008). Talent management: A strategy for improving employee recruitment, retention and engagement within hospitality organizations. International Journal of Contemporary Hospitality Management, 20(7), 743-757. https://doi.org/10.1108/09596110810899086

Daft, R. L. (2010). New Era of Management (9th ed.). International Edition, Boston, CENGAGE Learning.

Daft, R. L. (2013). Organization theory and Design (11th ed.). Boston, South CENGAGE Learning.

Das, B. L., \& Baruah, M. (2013). Employee retention: A review of literature. Journal of Business and Management, 14(2), 8-16. https://doi.org/10.9790/487X-1420816 
DeCenzo, D. A., \& Robbins, S. P. (2010). Human Resource Management, International Student Version. New York, John Wiley \& Sons.

Delgado Piña, M. I., María Romero Martínez, A., \& Gómez Martínez, L. (2008). Teams in organizations: a review on team effectiveness. Team Performance Management: An International Journal, 14(1/2), 7-21. https://doi.org/10.1108/13527590810860177

DeNisi A, Griffin R, (2010). Human Resource Management (6th ed.). Mason, OH: South-Western Cengage Learning.

Dessler, G. (2014). Fundamentals of Human Resource Management (3rd ed.). Boston: Irwin Prentice Hall.

DeVaro, J., \& Morita, H. (2013). Internal promotion and external recruitment: A theoretical and empirical analysis. Journal of Labor Economics, 31(2), 227-269. https://doi.org/10.1086/667814

Earnest, D. R., \& Landis, R. S. (2014). The Importance of Applicant Perceptions When Recruiting Employees to Teams. International Journal of Business and Social Science, 5(2). 81-91.

Festinger, L. (1950). Informal social communication. Psychological review, 57(5), 271-282. http://dx.doi.org/10.1037/h0056932

Gächter, S., Starmer, C., \& Tufano, F. (2017). Revealing the Economic Consequences of Group Cohesion. IZA Discussion Papers, No. 10824. Retrieved from https://ssrn.com/abstract=2988171

Garson, G. D. (2016). Partial least square: Regression and equation models. Asheboro, NC Statistical Publishing Associates.

Gërxhani, K., \& Koster, F. (2015). Making the right move. Investigating employers' recruitment strategies. Personnel Review, 44(5), 781-800. https://doi.org/10.1108/PR-12-2013-0229

Gross, N., \& Martin, W. E. (1952). On group cohesiveness. American Journal of Sociology, 57, 546-554. http://dx.doi.org/10.1086/221041

Heizer, J., Render, B., \& Munson, C. (2017). Operations management. Pearson Education Limited.

Heneman, H. G., Judge, T. A., Kammeyer-Mueller, J. D. (2012). Staffing Organizations (7th ed.). Middleton, WI: McGraw-Hill International Edition.

HM Tse, H. (2014). Linking leader-member exchange differentiation to work team performance. Leadership \& Organization Development Journal, 35(8), 710-724. https://doi.org/10.1108/LODJ-09-2012-0119

Holtbrügge, D., Friedmann, C. B., \& Puck, J. F. (2010). Recruitment and retention in foreign firms in India: A resource-based view. Human Resource Management: Published in Cooperation with the School of Business Administration, The University of Michigan and in alliance with the Society of Human Resources Management, 49(3), 439-455. https://doi.org/10.1002/hrm.20353

Jacobs, F. R., \& Chase, R. B. (2010). Operations management for competitive advantage (13th ed). Boston, Massachusetts: McGraw-Hill/Irwin.

Kebaili, S., Zanina, N., \& Arfa, Y. (2015). Impact of team cohesion on performance among Tunisian women soccer players. IOSR (International Organization of Scientific Research) Journal of Sports and Physical Education, 2(5), 15-18. https://doi.org /10.9790/6737-0251518

Kozlowski, S. W., \& Ilgen, D. R. (2006). Enhancing the effectiveness of work groups and teams. Psychological science in the public interest, 7(3), 77-124. https:// doi:10.1111/j.1529-1006.2006.00030.x. PMID 26158912

Krajewski, L. J., Ritzman, L. P., \& Malhotra, M. K. (2016). Operations Management: Processes and Supply Chains (14th ed.), New York: Pearson Prentice Hall.

Kumar, S., \& Suresh, N. (2009). Operations management. New Delhi: New Age

Locke, E. A. (2009). Hand book of principles of organizational behavior: Indispensable knowledge for evidence based management (2nd ed.). Southern Gate, John Wiley \& Sons.

Lott, A. J., \& Lott, B. E. (1965). Group cohesiveness as interpersonal attraction: A review of relationships with antecedent and consequent variables. Psychological Bulletin, 64(4), 259309.http://dx.doi.org/10.1037/h0022386

Luthans, F. (2011). Organizational Behavior: An Evidence-Based Approach (12th ed.). New York. McGraw Hill Irwin.

Mach, M., Dolan, S., \& Tzafrir, S. (2010). The differential effect of team members' trust on team performance: 
The mediation role of team cohesion. Journal of Occupational and Organizational Psychology, 83(3), 771794. https://doi.org/10.1348/096317909X473903

Maloney, M. L. (2018). Measuring Influence: A Critical Investigation in Internal Promotions Versus External Recruitment in Behavioral Health Care (Doctoral dissertation, Alvernia University).

Markova, G., \& T. Perry, J. (2014). Cohesion and individual well-being of members in self- managed teams. Leadership \& Organization Development Journal, 35(5), 429-441. https://doi.org/10.1108/LODJ-04-120058

Mathis, R. L., \& Jackson, J. H. (2010). Human Resource Management (13th ed.). South-Western College Publishing, Ohio.

McClurg, C. E., Chen, J. L., Petruzzelli, A., \& Thayer, A. L. (2017). Challenges and new directions in examining team cohesion over time. In Team Dynamics Over Time (pp. 261-286). Emerald Publishing Limited. https://doi.org/10.1108/S1534-085620160000018011

Mickan, S., \& Rodger, S. (2000). Characteristics of effective teams: a literature review. Australian Health Review, 23(3), 201-208. https://doi.org/10.1071/AH000201

Moh'd Abu Bakir, S. (2018). The Impact of Managers' Emotional Intelligence on Employees' Work Life Balance: A Field Study at Jordanian Private Hospitals. European Scientific Journal, ESJ, 14(25), 256-283. https://doi.org/10.19044/esj.2018.v14n25p256

Moh'd Abu Bakir, S. (2019). Human Resources Development Strategy and its Role in Promoting Employees Strategic Thinking Competencies: A Study at Jordanian Information Technology Companies. European Scientific Journal, ESJ, 15(4), 238-262. https://doi.org/10.19044/esj.2019.v15n4p238

Moser, K. (2005). Recruitment sources and post-hire outcomes: The mediating role of unmet expectations. International Journal of Selection and Assessment, 13(3), 188-197. https://doi.org/10.1111/j.14682389.2005.00314.x

Mullen, B., \& Copper, C. (1994). The relation between group cohesiveness and performance: An integration. Psychological Bulletin, 115(2), 210-227. http://dx.doi.org/10.1037/0033-2909.115.2.210

Muscalu, E. (2015). Sources of human resources recruitment organization. Land Forces Academy Review, 20(3), $351-359$

Mustafa, G., Glavee-Geo, R., \& Rice, P. M. (2017). Teamwork orientation and personal learning: The role of individual cultural values and value congruence. SA Journal of Industrial Psychology, 43(1), 1-13. https://doi.org/10.4102/sajip.v43i0.1446

Peñalver, J., Salanova, M., Martínez, I. M., \& Schaufeli, W. B. (2019). Happy-productive groups: How positive affect links to performance through social resources. The Journal of Positive Psychology, 14(3), 377-392. https://doi.org/10.1080/17439760.2017.1402076

Reid, Dan R.; Sanders, Nada R., (2012). Operations management (4th ed.). New York. John Wiley and Sons,

Russell, R. S., \& Taylor B. W. (2011). Operations management: Creating value along the supply chain (7th ed.). New Jersey, John Wiley \& Sons.

Schroeder, H. (2012). The importance of human resource management in strategic sustainability: An art and science perspective. Journal of Environmental Sustainability, 2(2), $4 . \quad 75-82$ https://doi.org/10.14448/jes.02.0004

Sekaran, U., \& Bougie, R. (2016). Research methods for business: a skill-building approach (7th ed.). Haddington: John Wiley \& Sons.

Snell, S. \& Bohlander, G. (2013) Managing human resources (16th ed.). Australia, South- Western Cengage Learning.

Spinelli Souza, F., \& Zajas, J. J. (1995). Recruiting executives in business: an organizational and conceptual perspective. Executive Development, 8(3), 23-27. https://doi.org/10.1108/09533239510086592

Stevenson, W. J., \& Sum, C. C. (2010). Operations management: an Asian perspective. (Asia), McGraw-Hill Education.

Tohidi, H. (2011). Teamwork productivity \& effectiveness in an organization base on rewards, leadership, training, goals, wage, size, motivation, and measurement and information technology. Procedia Computer Science, 3, 1137-1146. http://doi:10.1016/j.procs.2010.12.185 
Torrington, D. Hall, Laura. Taylor, Stephen \& Atkinson Carol (2014) Human Resource Management (9th ed.). Harlow, Pearson Education Limited.

Tuckman, B. W. (1965). Developmental sequence in small groups. Psychological bulletin, 63(6), 384-399. https://doi.org/10.1037/h0022100

Tuckman, B. W., \& Jensen, M. A. C. (2010). Stages of small-group development revisited. Group Facilitation: A Research \& Applications Journal, 10, 43-48. https://doi.org/10.1177/105960117700200404

Zaccaro, S. J., \& Lowe, C. A. (1988). Cohesiveness and performance on an additive task: Evidence for multidimensionality. The Journal of Social Psychology, 128(4), 547-558. https://doi.org/10.1080/00224545.1988.9713774

Zikmund, W. G., Babin, B. J., Carr, J. C., \& Griffin, M. (2013). Business research methods (8th ed.). Mason, Cengage Learning.

\section{Copyrights}

Copyright for this article is retained by the author(s), with first publication rights granted to the journal.

This is an open-access article distributed under the terms and conditions of the Creative Commons Attribution license (http://creativecommons.org/licenses/by/4.0/). 